\title{
HEALTH EDUCATION PEMERIKSAAN PAP SMEAR
}

\author{
Novita Anggraini \\ Program Studi S1 Ners Universitas Musi Charitas \\ Email : novitaanggraini06@gmail.com
}

\begin{abstract}
Abstrak
Kanker servik merupakan pembunuh wanita nomor satu didunia. Salah satu cara untuk mencegah meningkatnya kejadian kanker servik yakni dengan memeriksakan diri dengan cara pemeriksaan pap smear, penyuluhan merupakan salah satu cara yang dapat digunakan untuk menambah pengetahuan ibu tentang pentingnya pemeriksaan pap smear sehingga dapat menurunkan angka kejadian kanker servik pemeriksaan pap smear dilakukan untuk mengetahui sel kanker sedini mungkin sehingga pengobatan dapat dilakukan sedini mungkin,tujuan penelitian ini adalah untuk mengetahui pengaruh penyuluhan terhadap pengetahuan ibu tentang pentingnya pemeriksaan pap smear, penelitian ini adalah penelitian kuantitatif dengan metode Quasyexperiment dengan menggunakan teknik proporsional random samplingone group pre-test and post-test, sampel dalam penelitian ini sebanyak64 responden. Hasil penelitian ini dianalisa dengan menggunakan uji univariat didapatkan hasil bahwa rata-rata pengetahuan sebelum diberikan penyuluhan adalah 6,58 dan rata-rata pengetahuan setelah dilakukan penyuluhanadalah 16,57 dari hasil uji statistik wilcoxon didapatkan p-value 0,001 $\leq 0,05$ sehingga dapat disimpulkan bahwa ada pegaruh penyuluhan terhadap pengetahuan ibu tentang pentingnya pemeriksaan pap smear. Untuk itu pemeriksaan pap smear sangat penting dilakukan oleh ibu untuk mencegah terjadinya kanker servik.
\end{abstract}

Kata Kunci : Pap smear, Pengetahuan, Penyuluhan

\begin{abstract}
Cervical cancer is the number one killer of women in the world. One way to prevent an increase in the incidence of cervical cancer is by examining a pap smear, counseling is one way that can be used to increase the knowledge of mothers about the importance of pap smear examination so as to reduce the incidence of cervical cancer. cancer as early as possible so that treatment can be done as early as possible, the purpose of this study is to determine the effect of counseling on mother's knowledge about the importance of pap smear examination, this research is quantitative research with Quasyexperiment method using proportional random samplingone group pre-test and post-test techniques, the sample in this study were 64 respondents. The results of this study were analyzed using the univariate test showed that the average knowledge before giving counseling was 6.58 and the average knowledge after counseling was 16.57 from the results of the Wilcoxon statistical test obtained p-value $0.001 \leq 0.05$ so that it can be concluded that there is an influence of counseling on mother's knowledge about the importance of pap smear examination. For that pap smear examination is very important for mothers to prevent cervical cancer.
\end{abstract}

Keywords: Pap smear, Knowledge, Extension 


\section{PENDAHULUAN}

Kanker leher rahim atau yang disebut juga sebagai kanker serviks merupakan suatu penyakit yang disebabkan oleh HPV atau Human Papilloma virus onkogenik, Kanker serviks terjadi pada organ reproduksi wanita tepatnya pada leher rahim. Penyakit ini merupakan penyakit serius yang menyerang kaum wanita, kanker servik merupakan kanker yang tumbuh dari sel-sel serviks dapat berasal dari sel-sel dileher rahim tetapi dapat pula tumbuh dari sel-sel mulut rahim atau keduanya, pada tahap awal kanker servik tidak menimbulkan gejala, banyak masyarakat khususnya wanita yang tidak begitu menyadari pertumbuhan kanker serviks, untuk itu pap smear perlu dilakukan dalam upaya pencegahan terjadinya kanker servik (Andrijono, 2010).

Data Badan Kesehatan Dunia (WHO) pada tahun 2010 insiden penyakit kanker serviks terdapat 493.243 jiwa per tahun sedangkan kematian karena kanker ini sebanyak 273.505 jiwa per tahun dan sebanyak $80 \%$ dari jumlah penderita berasal dari negara-negara sedang berkembang. Penyakit ini merupakan urutan pertama pembunuh wanita akibat kanker di negaranegara berkembang (Wijaya, 2010).

Di Indonesia setiap tahun diperkirakan terdapat 100 penderita baru per 100.000 penduduk, ini berarti dari jumlah 237 juta penduduk ada sekitar 237.000 penderita kanker baru setiap tahunnya, sejalan dengan itu, data empiris juga menunjukkan bahwa kematian akibat kanker dari tahun ke tahun terus meningkat, berdasarkan hasil Riset kesehatan dasar tahun 2007, sekitar 5,7\% kematian semua umur disebabkan oleh kanker ganas di Indonesia prevalensi tumor/kanker adalah 4,3 per 1000 penduduk (Riskesdas, 2007)

Cakupan program scrining di Indonesia baru sekitar 5\% wanita yang melakukan pemeriksaan skrining pap smear tersebut sehingga hal itulah yang dapat menyebabkan masih tingginya kasus kanker serviks di Indonesia hampir 50\% penderita kanker serviks tidak melakukan pemeriksaan pap smear dalam 10 tahun belakangan disamping itu juga alasan para wanita untuk tidak melakukan pemeriksaan pap smear adalah psikologis yaitu takut, gelisah, khawatir atau cemas dalam pemeriksaan pap smear (Martini,2013).

Kesadaran wanita untuk melakukan pemeriksaan pap smear atau masih sangat rendah, sedangkan angka kesakitan maupun kematian akibat kanker serviks semakin tahun semakin meningkat, salah satu faktor penyebab meningatnya kejadian kanker serviks yakni kurangnya pengetahuan wanita mengenai pentingnya pemeriksaan pap smear, untuk itu penyuluhan kesehatan mengenai pap smear hendaknya dilakukan dalam peningkatan penetahuan wanita dan menurukan angka kematian wanita akibat kanker serviks.

Peneliti tertarik menggunakan tehnik dikarenakan penyuluhan dapat digunakan pada kelompok yang besar dan dalam waktu besamaan, sasaran penyuluhan yang peneliti lakukan yaitu semua ibu-ibu usia subur yang berada di Rw 01 wilayah kerja Puskesmas Sukarami Palembang yang membahas tentang pengetahuan ibu tentang pentingnya pemeriksaan pap smear. Metode yang dipakai peneliti adalah metode ceramah, metode ceramah ini dipakai cukup efektif karena ditinjau dari sampel yang ada yakni dengan kelompok besar tidak membutuhkan alat peraga yang banyak dan dapat menggunakan waktu yang sedikit dengan maksimal dan dapat dipakai pada kelompok dewasa (Maulana 2009).

Berdasarkan masalah tersebut maka peneliti tertarik untuk melakukan penelitian degan judul "Pengaruh Penyuluhan Terhadap Pengetahuan Ibu Tentang Pentingnya Pemeriksaan Pap Smear"

\section{METODE PENELITIAN}

Jenis penelitian yang peneliti lakukanmerupakan penelitian kuantitatif dengan metode Quasy experiment. Populasi yang digunakan dalam penelitian ini adalah semua ibu usia subur di rw 01 Wilayah Kerja Puskesmas Sukarami Palembang yang berjumlah 180 orang dengan 
menggunakan teknik proporsional Rondom Sampling. Jumlah responden yang digunakan pada penelitian ini berjumlah 64 orang.

Instrumen yang digunakan dalam penelitian ini adalah lembar kuesioner pretest dan post-test, denganjumlahkuesioner 20 pertanyaaanbilabenarnilainya 1 dansalahnilainya 0 degannilai minimal 0 danmaksimal $\quad 20 \quad$ yang dibagikankepadarespondenkuisioneriniuntuk mengetahuipengetahuanibutentangpentingny apemeriksaan pap smear, uji validitas dilakukan satu kali, pertanyaan yang mempunyai $r$ hitung lebih besar dari $r$ tabel $(0,444)$ yakni pertanyaan no $1,3,4,7,9,14,15,18$ dan 20 untuk uji reabilitas semua pertanyaan tersebut telah reable karena pertanyaan yang telah valit tersebut memiliki nilai $\mathrm{r}$ alpa yang lebih besar dari pada nilai $r$ konstanta alpa $(\mathrm{r} 0,706>\mathrm{r}$ konstanta 0,468). Kemudian pertanyaan yang tidak valid terdapat 11 pertanyaan yaitu pertanyaan no 2,5,6,8,10,11,12,13,16,17,19 kemudian pertanyaan ini dimodifikasi lsehingga kuesioner dalam penelitian ini sebanyak 20 pertanyaan dimana 9 pertanyaan yang telah valid ditambah 11 pertanyaan yang telah dimodifikasi.

\section{HASIL DAN PEMBAHASAN}

Rerata pengetahuan sebelum diberikan penyuluhan tentang pentingnya pemeriksaan pap smear.

Tabel 5.1 Rerata Pengetahuan Sebelum diberikan Penyuluhan

Dari hasil analisis didapatkan ratarata pengetahuan sebelum diberikan pengetahuan adalah 6,58 (95\% CI: 6.266.90), standar deviasi 1.270. pengetahuan terendah adalah 4 dan pengetahuan tertinggi adalah 10, dari hasil estimasi interval dapat disimpulkan bahwa 95\% diyakini bahwa rata-rata pengetahuan sebelum diberikan penyuluhan adalah diantara 6,26 sampai dengan 6,90 .

Menurut Notoadmojo (2010) pengetahuan merupakan hasil tahu seseorang terhadap objek melalui indra yang dimilikinya (mata, hidung, telinga, dll) dengan sendirinya pada waktu pengindraan sehingga menghasilkan pengetahuan tersebut dan sangat dipengaruhi oleh intensitas perhatian dan persepsi terhadap objek.

Menurut Wawan dan Dewi (2010) salah satu faktor yang mempengaruhi pengetahuan adalah pendidikan, pendidikan merupakan bimbingan yang diberikan seseorang terhadap perkembangan orang lain menuju ke arah cita-cita tertentu pendidikan diperlukan untuk mendapat informasi misalnya hal-hal yang menunjang kesehatan sehingga dapat meningkatkan kualitas hidup dan semakin tinggi pendidikan seseorang maka semakin mudah seseorang menerima suatu informasi.

Penelitian ini Sejalan dengan penelitian yang dilakukan oleh Lantu (2013) "judul Gambaran Pengetahuan dan Sikap ibu tentang pap smear di desa Pulubala kecamatan kabupate Gorontallo" yang meneliti tentang gambaran pengetahuan dan sikap ibu tentang pap smear didapatkan bahwa pengetahuan ibu dari jumlah sampel 215 orang ibu didapatkan hasil $(74,9 \%)$ responden berpengetahuan kurang.

Menurut asumsi peneliti, ibu dengan nilai terendah 4 dikarenakan terdapat $5 \mathrm{ibu}$ yang berpendidikan terakhir hanya sebatas SD saja, sehingga kemampuan dalam menjawab dan menganalisis soal dalam hal ini kuesioner berbeda dengan ibu-ibu pendidikan SMA karena dan Perguruan tinggi hal ini dikarenakan semakin tiggi

\begin{tabular}{lcccc}
\hline \hline Variabel & Mean & $\begin{array}{c}\text { Std. } \\
\text { Deviasi }\end{array}$ & $\begin{array}{c}\text { Min- } \\
\text { Max }\end{array}$ & $95 \%$ CI \\
\hline Pengetahu & 6.58 & 1.270 & $4-10$ & $6.26-$ \\
an & & & & 6.90 \\
sebelum & & & \\
Penyuluha & & & & \\
$\mathrm{n}$ & & & &
\end{tabular}

pendidikan maka semakin mudah orang menerima suatu informasi dan nilai tertingigi 10 menurut asumsi peneliti bahwa nilai tertinggi 10 dikarenaka dari 64 
responden terdapat 10 ibu yang berpendidikan perguruan tinggi sehingga analisis dan kemampuan untuk menjawab soal lebih baik kemudian dilihat dari segi pengalaman ibu dari hasil penelitian yang peneliti lakukan terdapat $3 \mathrm{ibu}$ yang sudah pernah melakukan pemeriksaan pap smear hal ini dapat pula berpengaruh pada saat pengisian kuesioner dikarenakan ibu sudah pernah memeriksaakan diri sebelumnya.

Rerata pengetahuan setelah diberikan penyuluhan tentang pentingya pemeriksaan pap smear

Tabel 5.2 Rerata pengetahuan setelah diberikan penyuluhan

\begin{tabular}{ccccc}
\hline \hline Variabel & Mean & $\begin{array}{c}\text { Std. } \\
\text { Devias } \\
\end{array}$ & $\begin{array}{c}\text { Min- } \\
\text { Max }\end{array}$ & 95\%CI \\
& & $\mathrm{i}$ & & \\
\hline $\begin{array}{c}\text { pengetahuan } \\
\text { setelah } \\
\text { penyuluhan }\end{array}$ & 16.75 & 1.260 & $14-19$ & $16.44-$ \\
& & & & 17.06 \\
\hline
\end{tabular}

Dari hasil analisis didapatkan ratarata pengetahuan sebelum diberikan pengetahuan adalah 16,75 (95\% CI: $16,44-$ 17,06), standar deviasi 1.260 pengetahuan terendah adalah 14 dan pengetahuan tertinggi adalah 19, dari hasil estimasi interval dapat disimpulkan bahwa 95\% diyakini bahwa rata-rata pengetahuan sebelum diberikan penyuluhan adalah diantara 16,44 sampai dengan 17,06 dilihat dari hasil setelah diberikan penyuluhan dengan nilai maksimum 19 poin, ini berarti penyuluhan yang peneliti berikan dimengerti oleh ibu-ibu dan dengan nilai terendah 14 poin.

Menurut teori yang dikemukaan oleh Maulana (2009) penyuluhan kesehatan hanya sebatas aspek kognitif bila dalam penyuluhan sudah dapat mengubah perilaku sasaran menjadi perilaku yang sehat maka tugas penyuluhan selesai.

Sejalan dengan penelitian yang dilakukan oleh Widyasari (2010) faktor yang mempengaruhi pengetahuan ibu tentang pentingnya pemeriksaan pap smear adalah pendidikan dari jumlah sampel sebanyak 263 orang responden didapatkan sebanyak (50,57\%) responden berpendidikan SD dan berpengetahuan kurang tentang pemeriksaan pap smear.

Menurut asumsi peneliti setelah peneliti melakukan post test kepada ibu-ibu usia subur di wilayah kerja Puskesmas Sukarami Palembang didapatkan bahwa terdapat perubahan pengetahuan pada ibuibu usia subur di Rw 01 wilayah kerja Puskesmas Sukarami Palembang dengan demikian penyuluhan yang peneliti berikan dapat diterima dengan baik oleh ibu-ibu di Rw 01.Sejalan dengan penelitian yang dilakukan oleh Widyasari (2010) dari 64 responden yang menjadi sampel dalam penelitian ini terdapat 5 ibu $(7,8 \%)$ berpendidikan SD sehingga tingkat analisis dan pemahaman ibu tentang pap smear masih kurang ditunjukkkan setelah dilakukan penyuluhan masih terdapat 6 pertanyaan salah yag berarti terdapat ibu yang hanya dapat menjawab 14 soal dengan benar, berdasarkan pengamatan yang peneliti lakukan setelah melakukan penyuluhan terjadinya peningkatan pengetahuan tentang pentingnya pemeriksaan pap smear setelah diberikan penyuluhan, ini berarti penyuluhan yang peneliti lakukan dapat diterima dengan baik ditunjukkan dengan nilai maksimum 19 yang berarti responden dapat menjawab 19 pertayaan benar dan 1 pertanyaan yang salah.

Perbedaan pengetahuan sebelum dan setelah dilakukan penyuluhan tentang pentingnnya pemeriksaan pap smear.

Tabel 5.5 Perbedaan pengetahuan sebelum dan setelah diberikan penyuluhan

\begin{tabular}{lccccc}
\hline \hline Variabel & $\mathrm{n}$ & Mean & $\begin{array}{c}\text { Std. } \\
\text { Devi } \\
\text { asi }\end{array}$ & $\begin{array}{c}\text { Sdt. } \\
\text { Eror }\end{array}$ & $\begin{array}{l}p \text { value } \\
\text { valu }\end{array}$ \\
\hline $\begin{array}{l}\text { Pengetahua } \\
\mathrm{n} \quad \text { sebelum } \\
\text { penyuluhan }\end{array}$ & 64 & 0.81 & 0.081 & 0.010 & 0,001 \\
$\begin{array}{l}\text { Pengetahun } \\
\text { sesudah } \\
\text { penyuluhan }\end{array}$ & 64 & 1.22 & 0.033 & 0.004 & \\
\hline
\end{tabular}


Dari tabel diatas didapatkan rata-rata pengetahuan sebelum diberikan penyuluhan adalah 0.81 dengan standar deviasi 0.081 pada rata-rata pengetahuan setelah diberikan penyuluhan adalah 1.22 dengan standar deviasi 0.033 terlihat perbedaan mean antara sebelum dan setelah penyuluhan adalah 0,41dengan standar deviasi 0,048 hasil uji statistik didapatkan nilai 0,001 maka dapat disimpulkan terdapat perbedaan signifikan antara pengetahuan sebelum dan setelah diberikan penyuluhan tentang pentingnya pemeriksaan pap smear.

Dari hasil uji statistik didapatkan $p$ value $\leq \alpha=0,05$ hal ini membuktikan bahwa ada perbedaan bermakna antara pengetahuan sebelum dan setelah diberikan penyuluhan terhadap pengetahuan ibu tentang pentingnya pemeriksaan pap smear dan ada cukup bukti untuk menerima Ha sehingga dapat disimpulkan bahwa ada pengaruh penyuluhan terhadap pengetahuan ibu tentang pentingnya pemerikssaan pap smear.

Hal ini sejalan dengan teori menurut Notoadmodjo (2012) yang menyebutkan bahwa penyuluhan merupakan upaya untuk menyampaikan pesan kesehatan kepada masyarakat, kelompok atau individu dengan adanya informasi tersebut maka masyarakat memperoleh pengetahuan dan pada akhirnya diharapkan berpengaruh pada perubahan perilaku.

Menurut Wawan dan Dewi (2010) salah satu faktor yang mempengaruhi pengetahuan adalah umur semakin dewasa seseorang maka maka dipercayai bahwa mempunyai pengalaman yang lebih matang dan pengetahuan yang lebih luas, semakin dewasa seseorang diyakini semakin matang pengalaman dan kematangan jiwanya.

Peyuluhan kesehatan merupakan upaya untuk menyampaikan pesan kesehatan kepada masyarakat, kelompok, atau individu dengan adanya informasi tersebut maka diharapkan masyarakat, kelompok atau individu dapat memperoleh pegetahuan tentang kesehatan yang lebih baik pengetahuan ini akhirnya diharapkan dapat berpengaruh terhadap perilaku, dengan kata lain adanya promosi tersebut diharapkan perubahan perilaku. (Notoadmodjo, 2012)

$$
\text { Penyuluhan kesehatan juga }
$$

merupakan suatu kegiatan yang mempunyai masukan (input) proses dan keluaran (output) kegiatan promosi kesehatan guna mencapai tujuan yakni perubahan perilaku, dipengaruhi oleh banyak faktor disamping faktor metode, faktor materi atau pesannya, petugas yang melakukannya, juga alat-alat bantu peraga (media) yang dipakai agar mencapai suatu hasil yang optimal, maka faktor-faktor tersebut harus bekerja sama secara harmonis hal ini berarti bahwa untuk materi juga harus disesuaikan dengan sasaran atau media. Untuk sasaran kelompok maka metode yang digunakan harus berbeda denga sasaran massa dan sasaran individu (Notoatmodjo, 2012).

Sejalan dengan penelitian yang dilakukan oleh Yulia 2012 dengan judul faktor-faktor yang berhubungan dengan pemeriksaan pap smear di instalasi rawat jalan kebidanan RSUP dr. Muhammad Hosein Palembang dengan jumlah responden 57 responden didapatkan bahwa tingkat pengetahuan ibu cukup yakni 22 orang (38.6\%), sebagian besar ibu mempunyai pengetahuan yang kurang tentang pemeriksaan pap smear.

Menurut asumsi peneliti peyuluhan merupakan suatu cara yang cukup efektif dalam peningkatan pengetahuan seseorang dalam hal ini khususnya ibu-ibu usia subur yang berada di Rw 01 kelurahan Sukarami Palembang peneliti berpendapat bahwa untuk menurunkan angka kejadian kanker servik yang semakin tahun semakin menigkat presentasenya.

Didukung oleh pendidikan ibu yang sebagian besar berpendidikan SMA sehingga dalam menjawab dan menganalisis soal dapat berjalan dengan baik, Dari hasil penelitian yang peneliti lakukan ibu mempunyai pendidikan sekolah menengah atas terdapat $48 \mathrm{ibu}(75 \%)$ dan terdapat 10 ibu yang mempunyai pendidikan akhir perguruan tinggi sehingga dalam menjawab dan menganalisis kuesioner yang peneliti berikan dapat dilaksanakan dengan baik dan 
dibuktikan pada saat dilakukan uji wilcoxon terdapat pengaruh sebelum dan setelah dilakukan penyuluhan.

Dilihat dari segi umur responden terdapat $13 \mathrm{ibu}(20,3 \%)$ yang berumur 45 tahun sehingga sejalan dengan teori yang dikemukakan oleh Wawan dan Dewi (2010) salah satu faktor yang mempengaruhi pengetahuan adalah umur semakin dewasa seseorang maka maka dipercayai bahwa mempunyai pengalaman yang lebih matang dan pengetahuan yang lebih luas, semakin dewasa seseorang diyakini semakin matang pengalaman dan kematangan jiwanya sehingga dalam mejawab kuesioner yang peneliti berikan dengan baik.

Keberhasilan penyuluhan ini dikarenakan pada saat dilakukan penyuluhan di Rw 01 para ibu cukup antusias mendengarkan penyuluhan yang peneliti berikan, ini sehubungan dengan sebelum diberikannya penyuluhan ibu-ibu di Rw 01 sebagian besar belum mengetahui tentang pemeriksaan pap smear.Didukung oleh tempat yang nyaman sehinggga penyampaian materi dapat disampaikan dengan baik, setelah materi selesai di sampaikan ibu-ibu di Rw 01 cukup antusias dan aktif bertanya mengenai pentingya pemeriksaan pap smear, kemudian setelah selesai sesi tanya jawab peneliti memberikan kuesioner post tes kepada responden dan setelah diuji secara statistik terjadi peningkatan pengetahuan dengan nilai terendah 14 dan nilai tertinggi 19, peneliti menggunakan tehnik penyuluhan untuk menambah pengetahuan ibu-ibu tentang pentingnya memeriksakan diri agar dapat mencegah sedini mungkin terjadinya kanker servik sehubungan bahwa tanda dan gejala kanker servik yang tidak terlihat pada stadium awal

maka para ibu wajib memeriksakan diri agar terhindar dari kanker servik dengan cara pemeriksaan pap smear.

\section{KESIMPULAN}

Dari hasil penelitian dan pembahasan yang telah peneliti lakukan, maka dapat disimpulkan bahwa :Pengetahuan sebelum dilakukan penyuluhan tentang pentingnya pemeriksaan pap smear di wilayah kerja Puskesmas Sukarami Palembang dengan nilai mean 6.58 dan standar deviasi 1.270dan Pengetahuan setelah dilakukan penyuluhan tentang pentingnya pemeriksaan pap smear di wilayah kerja Puskesmas Sukarami Palembang dengan nilai mean 16.75 dan standar deviasi 1.260 dan dilihat dari hasil nilai rata-rata ada perbedaan bermakna antara pengetahuan sebelum dan setelah dilakukan intervensi (penyuluhan) tentang pentingnya pemeriksaan pap smear dengan $p$-value $=0,001$.

\section{SARAN}

Berdasarkan kesimpulan di atas, maka peneliti memberikan saran sebagai berikut:

1. Bagi Puskesmas

Diharapkan untuk puskesmas Sukarami Palembang untuk membuat program untuk Penyuluhan tentang pemeriksaan pap smear dikarenakan masyarakat banyak yang belum mengetahui tentang pemeriksaan pap smear. 2. Peneliti

Peneliti selanjutnya diharapkan dapat melanjutkan penelitian ini dengan menambahkan variabel lain sebagai contoh variabel sikap dari pasien tentang pentingya pemeriksaan Pap smear serta menggunakan metode lain seperti menggunakan metode kualitatif untuk mengetahui lebih mendalam tentang pendapat ibu tentang pemeriksaan pap smear. 


\section{DAFTAR PUSTAKA}

Kurniawan.B.2013.Hubungan Pengetahuan Pada Pemeriksaan Pap Smear Pada Wanita Pekerja Seks Komersial. Www.Jkb.Ub.Ac.Id/Index.Php/Jkb/Art icle/Download/169/152.diakses

Tanggal 8 Mei 2014

Dahlan,M.S.2013.Statistik Untuk Kedokteran Dan Kesehatan. Jakarta: Salemba Medika

Darma, Kelana Kusuma.2011.Metodologi Penelitian Keperawatan. Jakarta: Trans Info Media

Depkes.2012.Http://Www.Depkes.Go.Id/Do wnloads/Buletin\%20mnte.Pdf. diakses Tanggal 4 Mei 2014.

Dewi M,wawan.2011.Teori dan Pengukur Pengetahuan Sikap dan Perilaku Manusia dilengkapi contoh kuesioner.Yogyakarta:Nuha Medika

\section{HidayatM,Dkk.2009.Keterampilan Dasar Praktik Klinik Untuk Kebidanan.Jakarta :Salemba Medika.}

Hidayat, Aziz Alimul. 2009. Metode Penelitian Keperawatan Dan Tehnik Analisa Data. Jakarta: Salemba Medika

$\mathrm{Ni}$ Ketut Martini.2013.Hubungan Karakteristik, Pengetahuan Dan SikapWanita Pasangan Usia Subur Dengan Tindakan Pemeriksaan Pap Smear di PuskesmasSukawati.(Online).Http://W ww.Pps.Unud.Ac.Id/Thesis/Pdf_Thesi s/Unud-778-265413185-

Tesis\%20ni\%20ketut\%20martini\%20 mikm\%

20unud\%20npm\%201092161018\%20j
uli\%202013\%20final.Pdf.di akses Tanggal 8 Mei 2014

Nurlela Lantu. 2013 Gambaran Pengetahuan Dan Sikap Ibu Tentang Pap Smear Di Desa Pulubala Kecamatan Pulubala Kabupaten Gorontalo Tahun 2013..Http://Kim.Ung.Ac.Id/Index.Ph p/Kimfikk/Article/View/2794/2770.di ankses PadaTanggal 8 Mei 2014

Pemerintah Targetkan 80\% Perempuan Dapat Deteksi Dini Kanker Payudara Dan

KankerServiks.2013.(online). $\mathrm{Http}: / / \mathrm{W}$ ww.Depkes.Go.Id/Index.Php? $\mathrm{Vw}=2 \&$ $\underline{\mathrm{Id}=\text { Snr. } 13100003}$ di AksesPadaTanggal 08 Mei 2014

Wijaya Delia.2010.Pembunuh Ganas Itu Bernama Kanker Serviks.Jakarta :Sinar Kejora

Dewi,M dan wawan,A. (2010). Pengetahuan, Sikap dan perilaku manusia. Yogyakarta: Nuha Medika

Soekidjo Notoatmojo. (2012). Metodologi Penelitian Kesehatan. Jakarta: Rineka Cipta

Yoana Widyasari.(2010).Hubungan Antara Pengetahuan Dan Motivasi Wanita Pasangan Usia Subur (Pus) Dalam Melakukan Pemeriksaan Pap Smear Di Desa Mander Kecamatan Tambakboyo Kabupaten Tuban (Online).Http://Lppm.Stikesnu.Com/ Wp-Content/Uploads/2014/02/31.Pdf diakses pada Tanggal 08 Mei 2014 